\title{
Microstructural properties and cavitation behavior of hypereutectic Al-Si alloy obtained by rheocasting process
}

\begin{abstract}
The purpose of this study was to investigate possible application of AISi alloy produced by rheocasting process in cavitation conditions. A rheocasting process was used to refine the as cast microstructure and improve the mechanical properties of Al18wt\%Si alloy. Mechanical stirring was applied to the melt for different stirring time: 60,120,180s at different temperatures below the liquidus temperature of the alloy, using different stirring speed values, before pouring into a metallic mould. The microstructure of the cast samples was characterized by optical and scanning electron microscopy.

The paper investigates the effect of stirring speed and stirring time on the microstructure of AlSi alloy obtained by rheocasting procedure. The microstructure morphology and the alloy mechanical properties were found to depend on the stirring time and the stirring speed, and by using a suitable combination of these parameters it is possible to achieve high refinement efficiency by treating the melts in the semisolid state. Cavitation resistance of these samples has been tested. Mass loss of specimens was measured by an analytical method. The morphology of damaged surfaces of tested samples was examined using scanning electron microscopy (SEM). According to the results, it can be concluded that the samples of AlSi piston alloy prepared via rheocasting process, can be successfully applied in conditions where the cavitation resistance is needed.
\end{abstract}

Key words: Al-Si alloy, microstructure, rheocasting process, cavitation resistance.

\section{INTRODUCTION}

Cast aluminum alloys are widely used in automotive, aerospace industry, where they very successfully to replace steel and cast iron. Metallurgical and mechanical properties of these alloys significantly affect their cavitation resistance [1-3]. It is well known that grain morphology of the various phases present in alloys (eutectic silicon, primary silicon) influence the mechanical and cavitation behavior. Primary silicon particles and coarse and needle - shaped eutectic Si particles increase wear of these materials. Special attention has been paid to establish the effect of stirring time and the stirring speed on microstructure evolution and on the size and shape of Si particles in Al$18 \mathrm{wt} \% \mathrm{Si}$ alloy. The aim of this study was also improved distribution of particles in cast hypereutectic Al-Si alloy which leads to improved mechanical properties. Stir casting (or rheocasting) since its inception has attracted attention worldwide to control the microstructure and mechanical properties of cast alloys. Since stir casting process produces non-dendritic spherical-shaped aluminum grains and fine primary silicon particles [4-6].

Author's address: ${ }^{1}$ Tehnikum Taurunum College of Mechanical Engineering, Belgrade, Serbia, ${ }^{2}$ University of Belgrade, Faculty of Technology and Metallurgy, Serbia

Received for Publication: 16. 07. 2013.

Accepted for Publication: 13. 10. 2013.
Cast aluminum-silicon alloys are weak in resisting cavitation erosion [7-9]. Cavitation erosion is a common damage phenomenon of cast aluminum alloys. Cavitation represent the formation and collapse of the bubbles in a liquid due to local pressure changes. When the liquid that contains bubbles is subjected to higher hydrostatic pressure, the bubbles can collapse suddenly. These collapses can cause cavitation fatigue of material surface through shock waves and microjets. Cavitations investigations proved that cavitations resistance of materials such as metal alloys commonly used in production of hydraulic machinery parts depends of mechanical properties (especially hardness) and microstructure $[10,11]$. The cavitation damage was determined by the mass loss during the experiment as well as the analysis of the microphotographs of sample surfaces the end testing.

\section{EXPERIMENTAL}

\section{Material}

Rheocast samples were used for laboratory testing of cavitation resistance in this paper.

The chemical composition (in wt\%) of aluminum silicon alloy was as follows: $18 \mathrm{Si}, 0.8-1.5 \mathrm{Cu}$, 0.8-1.3 Mg, 0.8-1.3 Ni, 0.7 Fe, 0.2 Zn, 0.2 Mn, and Al (balance).

The experimental set-up used in this work consisted of a laboratory electric resistive $2 \mathrm{~kW}$ furnace (with additional temperature control equipment) and a mixer. 
The crucible inside the furnace was made by a special procedure out of alumina and has an opening in the wall for introducing a thermocouple to $20 \mathrm{~mm}$ from the bottom of the crucible. It was possible to record and change the number of revolutions of the mixers shaft. The active part of the mixer is plate like whilst the ratio of the circle which the mixer traces to the inner diameter of the crucible is 0.53 .

In each experiment, specimens of $15 \mathrm{~mm}$ diameter and $27 \mathrm{~mm}$ height were cut from the master ingot. They were put into alumina crucible that were placed into an electric resistance furnace and were remelted at $993 \mathrm{~K}$ and then held at this temperature for a period of $3 \mathrm{~min}$. After this period, the alloy was cooled in the furnace and sheared at different stirring speed. To identify the effects of stirring speed and time on the microstructures, stirring time (s): $60,120,180$ and stirring speed in range of (rpm): 1000,1500 were employed.

\section{Methods}

All samples were being prepared for microstructural tests applying standard metalograhic procedure of polishing and etching of the samples (by Keler's agent). Microstructural tests were carried out by applying optical and scanning electron microscopy SEM (JEOL JSM - 5800, Tokyo, Japan) with EDX (energy dispersive $\mathrm{X}$ ray).

The changes in microstructure caused by stirring were tested by image analyses of the specimen micrographs using the Image Pro Plus Program. Equivavlent diameter of $\mathrm{Si}$ is defined as the diameter of circle having the same area as $\mathrm{Si}$ particles.

Vickers hardness was measured by using a universal hardness tester (BRIVISKOP WPM VEB WERKSTOFFPRÜFMASINEN-LEIPZEG), under $5 \mathrm{~N}$ loads. Hardness was measured at four points and the average was taken for study.

Cavitation test was performed using an ultrasonic equipment according to ASTM Standard G32-92 (the stationary specimen method).

In order to obtain the erosion curves, the mass loss measurements were performed after each exposure interval. The evaluation of the mass losses of the test specimens was performed using an analytical balance with an accuracy of $0.1 \mathrm{mg}$. Before being weighted, the test specimens were dried in a dryer at $383 \mathrm{~K}$ for $1 \mathrm{~h}$. The measurements were performed after subjecting each test specimen to cavitation for 1 hour. The duration of the tests was $4 \mathrm{~h}$. The microstructure changes after cavitation erosion testing were recorded by the SEM (JEOL JSM - 5800, Tokyo, Japan) with EDX (energy dispersive $\mathrm{X}$ ray).

\section{RESULTS AND DISCUSSION}

Optical micrographs Fig1. show that the microstructure of the Al18wt\%Si alloy stirring at the $1000,1500 \mathrm{rpm}$ leads to the formation of different size of $\alpha-$ Al particles.
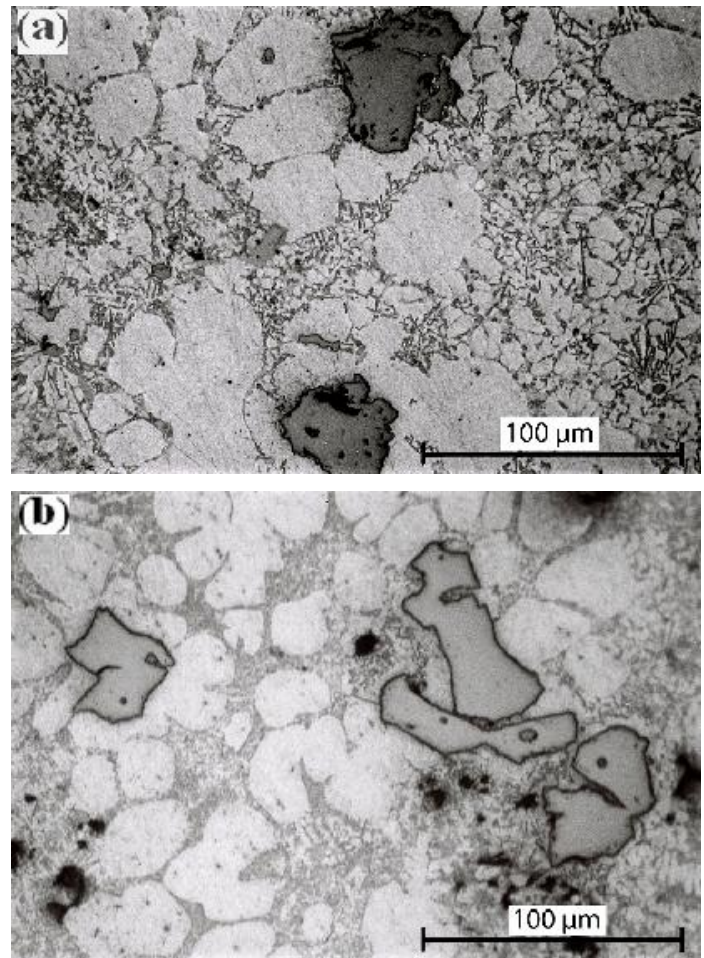

Fig. 1 - Microstructure of Al18wt\%Si alloy: a) stirring speed 1000rpm, after 60s; b) stirring speed $1500 \mathrm{rpm}$, after $60 \mathrm{~s}$

After $60 \mathrm{~s}$, the stirring of melt promoted formation Al grains with average size around $104 \mu \mathrm{m}$. This can be explained by a large density of nucleation centers leading to the formation of large number globular grains with small grain size. At a later stage of solidification (after 120,180s), stirring promoted the formation of different size of Al grains with average size around $120 \mu \mathrm{m}$ and $132 \mu \mathrm{m}$, respectively. The occurrence of larger particles is likely due to the agglomeration of smaller particles. The size of $\mathrm{Al}$ grains for sample stirring at the 1500, after s: $(60,12,180)$ was $60-108 \mu \mathrm{m}$.

The distribution of Si particles in the samples, $\mathrm{Al}-18 \mathrm{wt} \% \mathrm{Si}$ for both stirring speed and mixing time of $60 \mathrm{~s}$ is shown in Fig. 2.

It is clear that congregation of primary $\mathrm{Si}$ particles occurred in samples stirred at both stirring speed, and the congregation degree is different from each other.

These indicate that the clusters were formed by congregating of many single primary $\mathrm{Si}$ particles due to mechanical stirring. It is noted that the congregation phenomenon was more evident when the stirring speed was $1500 \mathrm{rpm}$. 

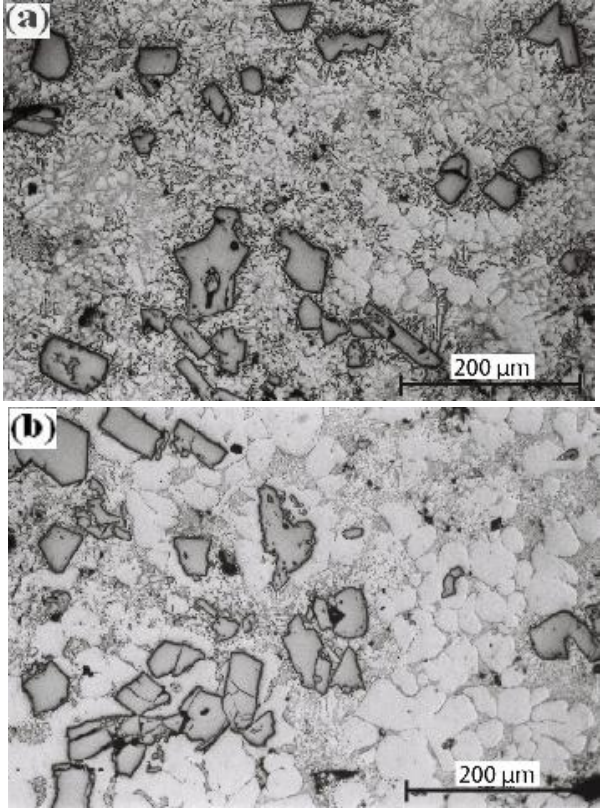

Fig.2 - Distribution of Si particles: a) stirring speed $1000 \mathrm{rpm}$, after 60s; b) stirring speed 1500rpm, after 60s

Fig.2 shows primary $\mathrm{Si}$ particles are already connected to each other, these mean that single Si particles continued growing after congregating connected gradually and merged each other finally. In order to investigate the influence of the stirring speed on the equivalent diameters of primary Si particles at different stirring time are calculated and shown in Fig. 3.

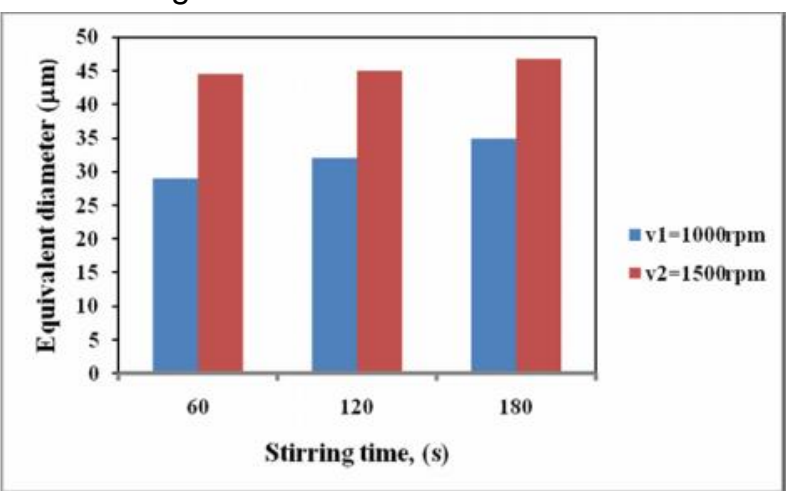

Fig. 3 - Average particle size of primary silicon of rheocast samples

The result means that the primary Si particles can be refined by mechanical stirring in all cases, and lower mechanical stirring is more effective than strong for the purpose. Fig.3 shows the way primary Si crystals grow during solidification of the samples. It is clear from the Fig. 3 that as the stirring time increase average size of the primary $\mathrm{Si}$ crystals increases. The increase of the average size of primary Si crystals, observed at different stirring time can be attributed to the agglomeration of Si particles. The diameter of the Si particles is decided by the cooperation of the congregation effect and refining effect of stirring.
The size and the shape of the primary silicon particles as well as the morphology of the etectic Si has a great effect on the mechanical properties of these alloy. Samples with significant refinement of primary silicon particles were used for hardness testing. Hardness measurement was carried out in the samples for both stirring speed after stirring time of $60 \mathrm{~s}$. The samples obtained at the sitirring speed of 1500rpm presented lower hardness (95VHN) compared to the samples obtained at the stirring speed of 1000rpm (99VHN). Such hardness growth may be attributed to smaller paricles of primary silicon and to a better modification of eutectic silicon, as well as to a better chemical homogenity created with application of lower stirring speed.

These samples were used for cavitation testing. The aim of cavitation erosion tests in laboratory conditions was to foresee an exploitation possibility for these materials in the conditions of exposure to cavitation effect.

Mass loss and surface analysis of samples during the experiment were used as an indicator to determine the level of sample surface damage caused by cavitation tests.

Total mass of the samples was determined from the difference of their mass before and after cavitation experiments and measured the analytical balance.

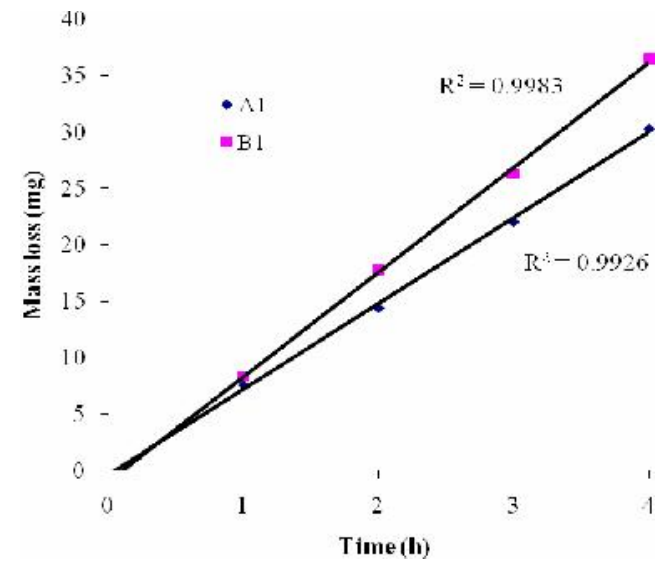

Fig.4 - Cavitation erosion of tested samples as a function time

Fig. 4 shows relation between mass loss and testing time, where the lines were drawn by leastsquare method and data can be expressed by a straight line. The slope of the straight line represents the cavitation rate. The calculated slope for rheocast Al18wt\%Si (1000rpm, 60s) corresponds to the cavitation rate of $0.126 \mathrm{mg} / \mathrm{min}$. The calculated slope for Al18wt\%Si (1500rpm,60s) was 0.152 $\mathrm{mg} / \mathrm{min}$. Regression analysis showed excellent correlation, with coefficient of correlation of $R^{2}=0.9926$ for rheocast Al18wt\%Si (1000rpm, 60s), sample $A$ and $R^{2}=0.9983$ for Al18wt\% Si (1500rpm, 60 s), sample $B$ respectively.

The surface deterioration observed on the samples and microphotograph of sample $A$ at the end the experiment is presented in Fig 5. 


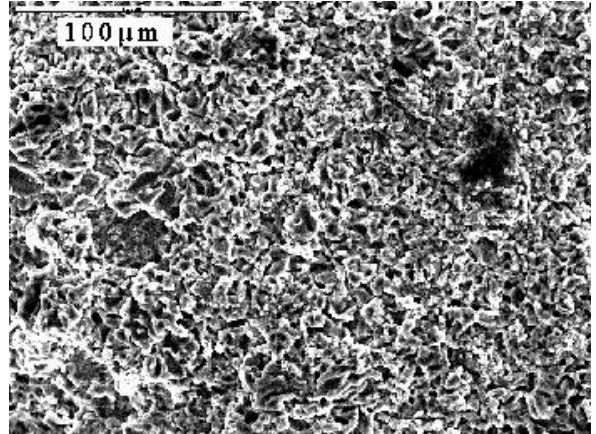

Fig. 5 - Image of the sample $A$ after $4 \mathrm{~h}$

\section{CONCLUSION}

The subject of our investigation was monitoring and analyzing of microstructural and mechanical properties as well as cavitation behaviour of these alloys using the modified vibratory cavitation setup.

Different shape and size of silicon particles and primary alpha phase are believed to be responsible for different mechanical properties in various casting methods of $\mathrm{Al}-\mathrm{Si}$ alloy.

For the processing conditions used on this work the results showed that:

Size of primary of $\alpha-\mathrm{Al}$ increase with an increase in the stirring time.

Refinement of primary Si particles, finer and uniformly distributed $\mathrm{Si}$ particles in stir cast samples (A) is better in comparison with sample (B).

The results presented in this paper show that the stir cast alloy obtained at high stirring speed 1500rpm show lower hardness which leads to less cavitation resistance.

Cavitation rate of stir cast alloy produced using 1000rpm stirring speed was found lower then those produced by using 1500 rpm.

The results obtained suggested that the rheocast AISi alloy could be a very good choice for application in case where the cavitation resistance is required.

\section{Acknowledgements}

This investigation was supported by the Ministry of Education and Science of the Republic of Serbia and it was conducted under the project TR 35002.

\section{REFERENCES}

[1] B.K. Prasad, K.Venkateswarlu, O.P.Modi, A.K. Jha, S.Das, R.Dasgupta, A.H. Yegnes waran, (1998) Sliding Wear Behavior of some Al-Si Alloys: Role of Shape and Size of Si Particles and Test Conditions, Metall. Mater. Trans. A, 29, 2747-2752.

[2] D. K. Dwivedi, (2003) Interface Temperature and Wear Behaviour of Cast Al-Si Alloys, Mater. Sci. Tech-Lond., 19, 1091-1096

[3] D. K. Dwivedi, T.S. Arjun, P. Thakur, H. Vaidya, K. Singh, (2004) Sliding Wear and Friction Behaviour of Al-18\% Si-0.5\% Mg Alloy, J. Mater. Process. Tech., 152 (3), 323-328.

[4] P. Falak, B. Niroum, (2005) Rheocasting of an AlSi Alloy, Scripta Mater., 53, 53-57.

[5] Z. Fan, (2002) Semi Solid Metal Processing, Int. Mater. Rev., 47 (2), 1-38.

[6] H.C. Man, C.T. Kwok, T.M. Yue, (2000) Cavitation Erosion and Corrosion Behaviour of Laser Surface Alloyed MMC of $\mathrm{SiC}$ and $\mathrm{Si}_{3} \mathrm{~N}_{4}$ on Al Alloy AA6061, Surf. Coat.Tech., 132, 11-20.

[7] W. J. Tomlinson, S.J. Matthews, (1994) Cavitation Erosion of Aluminium Alloys, J. Mater. Sci., 29, 1101 $-1108$

[8] K.Kondoh, J.Umeda, R.Watanable, (2009) Cavitation Resistance of Powder Metallurgy Aluminum Matrix Composite with AIN Dispersoids, Mater. Sci. Eng. A, 499, $440-444$.

[9] W. J. Tomlinson, A.S. Bransden, (1995) Cavitation Erosion of Laser Surface Alloyed Coatings on Al12\%Si, Wear, 185 (1-2), 59-65.

[10] C.E. Brennen, Cavitation and Bubble Dynamics, Oxford University Press, 1995.

[11] F.G. Hammitt, Cavitation and Multiphase Flow Phenomena, McGraw-Hill, New York,1980.

\section{IZVOD}

\section{MIKROSTRUKTURNA SVOJSTVA I KAVITACIONO PONAŠANJE NADEUTEKTIČKE Al-Si LEGURE DOBIJENE REOKASTING POSTUPKOM}

Cilj ovog istraživanja je bio da se ispita mogućnost primene AISi legure dobijene reokasting postupkom u kavitacionim uslovima. Reokasting postupak je korišćen kako bi se poboljšala mikrostruktura i mehanička svojstva Al18\%Si legure. Primenjeno je mehaničko mešanje rastopa različitim brzinama mešanja, pri različitim vremenima mešanja od 60,120 i 180s, na različitim temperaturama ispod likvidus temperature pre livenja u metalni kalup.

Karakterizacija mikrostrukture livenih uzoraka izvedena je pomoću optičkog i skenirajućeg elektronskog mikroskopa. U radu je ispitivan uticaj brzine $i$ vremena mešanja na mikrostrukturu legure, koja je dobijena pomenutim postupkom. Utvrđeno je da mikrostrukturna morfologija i mehanička svojstva zavise kako od brzine mešanja tako i od vremena mešanja, i da se podesnom kombinacijom ovih parametara mogu postići visoka rafinirajuća svojstva rastopa, koji je procesiran u oblasti poluočvrslog stanja.

$U$ radu je ispitivana kavitaciona otpornost uzoraka. Gubitak mase meren je primenom analitičke metode. Morfologija oštećenih površina uzoraka ispitivana je pomoću SEM-a. Prema rezultatima ispitivanja, može se zaključiti da se uzorci AlSi klipnih legura dobijenih reokasting postupkom, mogu uspešno primeniti u uslovima gde je potrebna kavitaciona otpornost.

Ključne reči: Al-Si legure, mikrostruktura, reokasting postupak, kavitaciona otpornost.

Originalni naučni rad

Primljeno za publikovanje: 16. 07. 2013

Prihvaćeno za publikovanje: 13. 10. 2013. 